\title{
PENANDA KEKUASAAN DI DALAM CERITA ANAK SULTHĀN LI YAUMIN WĀHID KARYA YA'QŪB ASY-SYĀRŪNI
}

\author{
Ulfah Raihan \\ Fakultas Ilmu Budaya, Universitas Padjadjaran \\ ulfah14005@mail.unpad.ac.id \\ Sri Rijati Wardiani \\ Fakultas Ilmu Budaya, Universitas Padjadjaran \\ sri.rijati@unpad.ac.id \\ Amaliatun Saleha \\ Fakultas Ilmu Budaya, Universitas Padjadjaran \\ amaliatun.saleha@unpad.ac.id
}

\begin{abstract}
Abstrak
Artikel jurnal ini menyajikan hasil penelitian tentang keberadaan penanda-penanda kekuasaan di dalam cerita anak Mesir berjudul Sulthān li Yaumin Wāhid 'Raja Sehari' (2008) karangan Ya'qūb Asy-Syārūnī. Praktik-praktik mendominasi dan didominasi terjadi di antara para tokoh di dalam cerita. Masalah pokok yang disoroti di dalam artikel jurnal ini adalah penandapenanda kekuasaan yang ada pada tokoh yang mengindikasikan adanya makna kekuasaan dalam perspektif semiologi Roland Barthes. Penelitian ini dilakukan untuk mendeskripsikan penanda-penanda kekuasaan yang ada di dalam cerita serta mengidentifikasi signifikasi melalui metode kajian sastra kualitatif dengan analisis tekstual memanfaatkan teori semiologi Roland Barthes, yaitu konsep tingkatan signifikasi berupa relasi penanda dan petandanya dalam sebuah tanda (denotasi) serta relasi tanda dengan acuannya dalam realitas eksternal (konotasi). Hasil penelitian menunjukkan ditemukannya makna-makna kekuasaan melalui identifikasi 6 kelompok jenis penanda, yaitu berupa busana, sikap dan tuturan, tempat tinggal, barang dan makanan mewah, orang-orang dekat, serta wewenang raja yang dikaitkan dengan tanda budaya. Penanda-penanda tersebut mengonotasikan pada raja sebagai pemilik kekuasaan yang merupakan orang berkelas tinggi, bertaraf hidup tinggi, mulia, dan paling istimewa yang harus dipatuhi, dilayani, serta diberikan wewenang paling besar dalam segala urusan.
\end{abstract}

Kata kunci: penanda, budaya, kekuasaan, konotasi, semiologi Roland Barthes

\begin{abstract}
This journal article presents the result of research on the existence of signifier of power in an Egyptian children's story entitled Sulthān li Yaumin Wāhid 'King for One Day' (2008) by Ya'qūb Asy-Syārūnī. Dominating and dominated practices occur between the characters in the story. The main problem that is highlighted in this journal article is the signifier of power that exist in character that indicate the significance of power in the semiology perspective of Roland Barthes. This research was conducted to describe the signifier of power in the story and to identify the significance contained in it through the qualitative literature study method with textual analysis utilizing Roland Barthes semiology theory, namely the concept of significance levels in the form of the relation between the signifier and the signified in a sign (denotation) and the relation of the sign to its reference in external reality (connotation). The results of the research show that significance of power are found through the identification of 6 types of signifier, namely in the form of clothing, attitudes and speech, residence, luxury things and foods, close
\end{abstract}




\section{Raihan dkk.}

people, and associated king authority with a cultural sign. These signifier connote the king as the owner of power who is a person of high class, high standard of life, noble, and most special who must be obeyed, served, and given the greatest authority in all matters.

Keywords: signifier, culture, power, connotation, semiology Roland Barthes

\section{PENDAHULUAN}

Cerita anak termasuk salah satu media pemenuhan kebutuhan anak akan kesenangan dan pendidikan. Di tengah beragamnya genre cerita anak, tema-tema yang dominan dipilih pengarang melalui kisah-kisah kekuasaan seperti raja dan penguasa tidak sekadar menonjolkan kemampuan imajinasi pengarang, melainkan juga mengandung pesan (amanat) maupun informasi bagi pembaca. Keberadaan penanda-penanda di dalam cerita dapat membantu dalam mengungkap pesan serta informasi tersebut. Penanda memberikan petunjuk tentang identitas tokoh di dalam cerita, mulai dari benda yang dipakai, makanan yang dikonsumsi, aktivitas yang dilakukan, dan segala hal di dalam cerita. Misalnya, sudah lazim dan berterima di pikiran kita bahwa orang yang bermahkota adalah seorang raja atau ratu yang memiliki kuasa terbesar di suatu wilayah.

Hal itu sesuai dengan konsep tanda perspektif Roland Barthes yang dikutip oleh Lustyantie (2012: 3) bahwa tanda mengungkapkan gagasan (bermakna) yang terbentuk dari penanda-penanda dalam sebuah struktur. Berangkat dari teori penandaan Barthes yaitu mengenai tanda bahasa perspektif Ferdinand de Saussure bahwa tanda bahasa (sign) memiliki dua sisi, yaitu penanda berupa imaji bunyi ( sound image) dan petanda berupa konsep (Zaimar, 2008: 9). Saussure menjelaskan 'tanda' sebagai kesatuan yang tidak dapat dipisahkan dari 2 bidang, yaitu bidang penanda (signifier) untuk menjelaskan 'bentuk' atau 'ekspresi'; dan bidang petanda (signified) untuk menjelaskan 'konsep' atau 'makna' (Piliang, 2004: 191). Penanda adalah aspek material dari tanda sedangkan petanda adalah aspek konseptualnya (Anggoro, 2016: 25). Penelitian terhadap penanda-penanda kekuasaan ini diharapkan dapat menjelaskan bagaimana penanda berperan di dalam menentukan identitas tokoh (individu maupun masyarakat) dan mengungkap signifikasi maknanya.

Cerita anak Sulthān li Yaumin Wāhid dipilih sebagai objek penelitian ini karena memuat penanda-penanda kekuasaan di dalam ceritanya. Sulthān li Yaumin Wähid merupakan cerita anak berbahasa Arab dalam serial Al-Maktabah Al-Khadhrā 'Perpustakaan Hijau Bagi Anak-anak' yang dikhususkan bagi pembaca anak usia 1015 tahun yang dikategorikan sebagai remaja awal. Sulthān li Yaumin Wähid menceritakan tentang seorang pemuda malang bernama Abu Hasan yang kalah saing mendapatkan seorang gadis dan ditinggalkan teman-temannya karena dianggap telah habis warisan bapaknya (miskin). Suatu hari, seorang raja merasa iba kepadanya dan menjadikannya raja sehari sebagai bentuk balas budi atas kebaikan Abu Hasan yang telah menjamunya dengan sangat istimewa saat kondisinya jatuh miskin. Namun, Abu Hasan memanfaatkan posisi dan kekuasaannya tersebut untuk membalaskan dendamnya kepada orang-orang yang telah menghina dan menyakitinya hingga kondisi kembali ke semula dan Abu Hasan menyadari kesalahannya. Raja memberinya kesempatan kedua untuk menjadi raja sehari dan Abu Hasan mempergunakan dengan cara yang sebaliknya dari kesempatan pertama. Ia melewati ujian hingga mendapatkan apa yang pernah diinginkannya, yaitu restu 
untuk menikahi gadis anak penjual emas. Di dalam cerita tersebut, menjadi raja merupakan hal yang menyenangkan karena memiliki segala kapital kekuasaan.

Penanda-penanda di dalam cerita yang berlatar budaya masyarakat Arab tersebut akan dianalisis dengan memanfaatkan konsep tanda (semiologi) Barthes. Penanda budaya yang dimaksud berupa busana, sikap dan tuturan, tempat tinggal, barang dan makanan mewah, orang-orang dekat, serta wewenang yang melekat pada orang yang berkuasa. Kekuasaan pada penelitian ini berupa kekuasaan seorang raja di tengah masyarakatnya yang berkonteks negara Arab, spesifiknya kota Bagdad. Dalam sejarahnya, Bagdad pernah muncul menjadi pusat dunia dengan tingkat kemakmuran dan peran internasional yang luar biasa (Hitti, 2013: 375). Di sana pemerintahan silih berganti dan diperebutkan. Ia pernah mengalami kehancuran dan kemudian kembali bangkit (Hitti, 2013: 379). Secara geografis, Bagdad (Irak) terletak di Asia Barat dan termasuk kawasan Al-Hilāl Al-Khashīb (Bulan Sabit Subur). Ia menjadi kebanggaan tersendiri bagi negara-negara blok Arab: Suriah, Irak, dan Mesir (Asia Barat). Pada masa kejayaannya, dinasti Abasiyah masa kepemimpinan Harun Ar-Rasyid disebut-sebut sebagai contoh ideal kerajaan Islam yang menarik berbagai profesi, tak terkecuali pengarang/sastrawan, untuk mengadopsinya ke dalam karya mereka (Hitti, 2013: 377), antara lain kisah-kisah terkenal Abu Nuwas yang berlatar kerajaan Harun Ar-Rasyid dan kota Bagdad.

Dengan demikian, adanya relevansi penanda-penanda kekuasaan dengan kultural masyarakat Arab di dalam cerita mendorong lahirnya dua rumusan masalah dalam penelitian ini, yaitu bagaimana kekuasaan tersebut disimbolkan di dalam cerita Sulthān li Yaumin Wāhid serta penanda-penanda apa saja yang digunakan di dalam cerita tersebut? Adapun tujuannya adalah untuk mendeskripsikan temuan penanda-penanda kekuasaan yang ada di dalam cerita serta membuktikan bagaimana cerita anak sebagai media penyampai pesan memuat penanda-penanda yang signifikan.

\section{METODE PENELITIAN}

Inti teori semiologi Barthes sebenarnya menyangkut dua tingkatan signifikasi (Barthes, 2017: 8), yakni pemaknaan tingkat pertama atau dikenal dengan pemaknaan denotatif dan pemaknaan tingkat kedua atau dikenal dengan pemaknaan konotatif yang dapat membentuk mitos. Mitos-mitos menjalankan fungsi naturalisasi, yakni untuk membuat nilai-nilai yang bersifat historis dan kultural, sikap dan kepercayaan menjadi tampak "alamiah", "normal", "common sense", dan dianggap "benar" (Barthes, 2017: 9).

Barthes (2017: 127) menyebutkan bahwa sistem tanda terdiri dari taraf ekspresi (E), taraf isi (C), dan signifikasi yang bisa dideskripsikan sebagai relasi (R) dari dua taraf tersebut: E R C. Dengan demikian, konotasi terdiri dari penanda-penanda (konotator/tanda dalam sistem denotatif), petanda-petanda, dan signifikasi (Barthes, 2017: 129). Dari ketiga elemen tersebut, petanda-lah yang memiliki komunikasi yang sangat dekat dengan budaya, pengetahuan, dan sejarah yang melaluinya dunia sekitar kita membentuk sistem (Barthes, 2017: 130). Bagi Saussure yang juga membahas sistem semiologis, petanda adalah konsep, penanda adalah citra akustik, dan tanda adalah hubungan konsep dan citra (Barthes, 2007: 301-302). Barthes (2007: 310) menyebutkan bahwa konsep berkaitan dengan suatu fungsi serta didefinisikan 


\section{Raihan dkk.}

sebagai kecenderungan. Misalnya, berkenaan dengan penanda perilaku, ia mengemukakan petanda dalam sistem semiologi Freud yang menyatakan bahwa makna tatanan kedua dari perilaku adalah makna sebenarnya atau merupakan maksud perilaku. Dengan demikian, ketika penanda-penanda di dalam cerita, baik busana, makanan, perabot, maupun yang lainnya dianggap cocok satu sama lain bersejajar melekat pada kehidupan raja/penguasa, serta ide tersebut diterima dalam masyarakat, dibenarkan, dan dinaturalisasi seakan-akan sebuah kenyataan yang lazim, artinya elemen petanda telah berkomunikasi dengan sistem budaya yang bersangkutan dan mendorong terbentuknya konvensi baru.

Penelitian ini memanfaatkan sistem tanda dalam semiologi Barthes yang dikenal dengan E, $\mathrm{R}, \mathrm{C}$ (Expression, Relation, dan Content). Melalui rumusan $\mathrm{E}_{2}=\left(\mathrm{E}_{1} \mathrm{R}_{1}\right.$ $\left.\mathrm{C}_{1}\right) \mathrm{R}_{2} \mathrm{C}_{2}$ diketahui bahwa makna utama tanda adalah denotasi, sedangkan makna tingkatan kedua adalah konotasi yang disebut Fiske sebagai two order signification (Wibowo, 2013: 21). Konsep konotasi ini menjadi kunci dalam semiologi Barthes. Oleh karena itu, mengungkap makna konotatif berarti menghubungkan tanda dengan suatu kebudayaan tertentu. Penanda-penanda kekuasaan di dalam cerita Sulthān li Yaumin Wāhid menjadi elemen yang pertama kali diidentifikasi untuk mencapai pemaknaan tingkat pertama (denotasi) karena penanda memiliki realitas yang dapat ditangkap oleh indera (Barthes, 2007: 307). Selanjutnya adalah identifikasi petanda untuk mencapai pemaknaan tingkat kedua (konotasi). Petanda-petanda tersebut menunjukkan peran pembaca melalui tingkat pengetahuan yang berbeda menurut perbedaan latar "budaya" (Barthes, 2017: 67). Oleh karena itu, mencapai pengetahuan sampai pada latar "budaya" cerita diperlukan untuk dapat mengenali dan membongkar sistem penandaan kekuasaan di dalam cerita. Budaya dalam konsep tanda Barthes berupa realitas di masyarakat tentang bagaimana sesuatu dimaknai dalam arti konotatif. Barthes menyebutkan sistem penandaan terkait latar budaya yang mesti dikenali, antara lain pada sistem pakaian, makanan, mobil (transportasi), perabot rumah tangga, dan sistem arsitektur (Barthes, 2017: 90-91).

Dengan demikian, metode yang digunakan di dalam penelitian ini bersifat deskriptif kualitatif dengan tahapan operasional penelitian masalah: 1) pembacaan teks, 2) pemecahan teks untuk menemukan penanda-penanda kekuasaan, 3) pengelompokan jenis penanda kekuasaan, 4) pengamatan makna konotatif melalui deskripsi fisik maupun relasi dengan budaya. Adapun data primer yang digunakan adalah cerita anak Sulthān li Yaumin Wāhid yang diterbitkan oleh Dārul Ma'ārif.

\section{HASIL DAN PEMBAHASAN}

Berdasarkan hasil pembacaan teks cerita anak Sulthān li Yaumin Wähid, diketahui bahwa praktik dominasi (berkuasa) terbanyak dilakukan oleh tokoh utama, Abu Hasan, saat berperan sebagai raja dengan berbagai kapital yang dimilikinya. Hal itu dilihat melalui penanda-penanda kekuasaaan yang ditampilkan tokoh di dalam cerita. Dengan demikian, praktik menguasai dilakukan oleh penguasa dalam konteks apapun. Faktor pendukungnya adalah status Abu Hasan sebagai seorang elit politik dan penguasa negara di mana kekuasaan, ekonomi, pasukan militer, dan segala aspek kehidupan kenegaraan ia kuasai dan kendalikan. Jadi, secara otomatis Abu Hasan (raja) memiliki wewenang untuk melakukan kebijakan walaupun pada 
kesempatan pertama ia bersikap otoriter di mana senantiasa mengeluarkan kebijakan yang tidak sesuai harapan rakyat.

Adapun penanda-penanda kekuasaan yang ditemukan di dalam cerita Sulthān li Yaumin Wāhid ini ditampilkan dalam tabel berikut ini:

Tabel 1. Simbolisasi Kekuasaan Raja Abu Hasan

\begin{tabular}{|c|c|c|c|}
\hline No & Teks & Hlm & $\begin{array}{c}\text { Jenis penanda } \\
\text { kekuasaan }\end{array}$ \\
\hline 1 & $\begin{array}{l}\text { Pakaian mewah yang dijahit emas dan perak serta } \\
\text { sorban besar khusus raja }\end{array}$ & 22 & Busana \\
\hline 2 & "Selamat pagi, Tuan Raja!" & 18 & Sikap dan tuturan \\
\hline 3 & $\begin{array}{l}\text { "Kami telah siapkan air panas yang dapat engkau } \\
\text { gunakan untuk mandi, Yang Mulia." }\end{array}$ & 20 & \\
\hline 4 & "Ini handukmu, silakan, Tuan raja." & 20 & \\
\hline 5 & $\begin{array}{l}\text { "Ini sepatumu yang akan membuat kakimu } \\
\text { nyaman, Yang Mulia." }\end{array}$ & 20 & \\
\hline 6 & "Saya di sini jika rambut Tuan perlu bantuan." & 20 & \\
\hline 7 & $\begin{array}{l}\text { "Selamat pagi, tuan. Apakah engkau izinkan saya } \\
\text { menyebutkan agenda Tuan hari ini?" }\end{array}$ & 21 & \\
\hline 8 & $\begin{array}{l}\text { Langkah yang lambat menunjukkan kebesaran dan } \\
\text { kewibawaan }\end{array}$ & 23 & \\
\hline 9 & $\begin{array}{l}\text { "Ambil semua hartanya dan masukkan ia di } \\
\text { penjara!" }\end{array}$ & 24 & \\
\hline 10 & $\begin{array}{l}\text { "Selamanya aku adalah raja, maka menteri agung } \\
\text { harus menjalankan perintah-perintahku!" }\end{array}$ & 24 & \\
\hline 11 & "Perintah-perintah raja kami ditaati, Yang Mulia." & 24 & \\
\hline 12 & “Taat dalam hal apapun tanpa lambat." & 24 & \\
\hline 13 & $\begin{array}{l}\text { "Tangkap laki-laki ini, paksa ia berkostum badut } \\
\text { dan letakkan ia di atas keledai dengan wajah yang } \\
\text { menghadap ekor, arak ia mengelilingi keramaian } \\
\text { Bagdad, dan di depannya ada orang yang } \\
\text { berteriak: Ini balasan bagi orang yang memaksakan } \\
\text { kehendaknya dan ia sembunyikan batang } \\
\text { hidungnya dari tetangganya." }\end{array}$ & 24 & \\
\hline 14 & $\begin{array}{l}\text { "Ini kehendak raja, gubernur harus mentaati } \\
\text { perintah-perintah raja!" }\end{array}$ & 26 & \\
\hline 15 & $\begin{array}{l}\text { "Di rumah ini engkau akan mendapati seorang } \\
\text { perempuan lansia. Berikan padanya lima ribu } \\
\text { dinar emas dan katakan padanya ini hadiah dari } \\
\text { raja." }\end{array}$ & 26 & \\
\hline 16 & "Kita di istanamu, benar, Ya Tuan." & 29 & \\
\hline 17 & $\begin{array}{l}\text { "Kami telah siapkan untukmu pesta yang berbeda } \\
\text { di sepanjang waktu untuk meringankan bebanmu } \\
\text { setelah perjuangan besar yang engkau lakukan } \\
\text { untuk menentukan berbagai keputusan di waktu } \\
\text { pagi. Kami berharap Tuan ridha terhadap usaha } \\
\text { kami memilihkan para pemusik, penyanyi, dan } \\
\text { penari." }\end{array}$ & 29 & \\
\hline 18 & $\begin{array}{l}\text { Kamar yang luas dengan lukisan-lukisan yang } \\
\text { menyerupai aneka ikan dan burung, atap yang }\end{array}$ & 21 & Tempat tinggal \\
\hline
\end{tabular}




\section{Raihan dkk.}

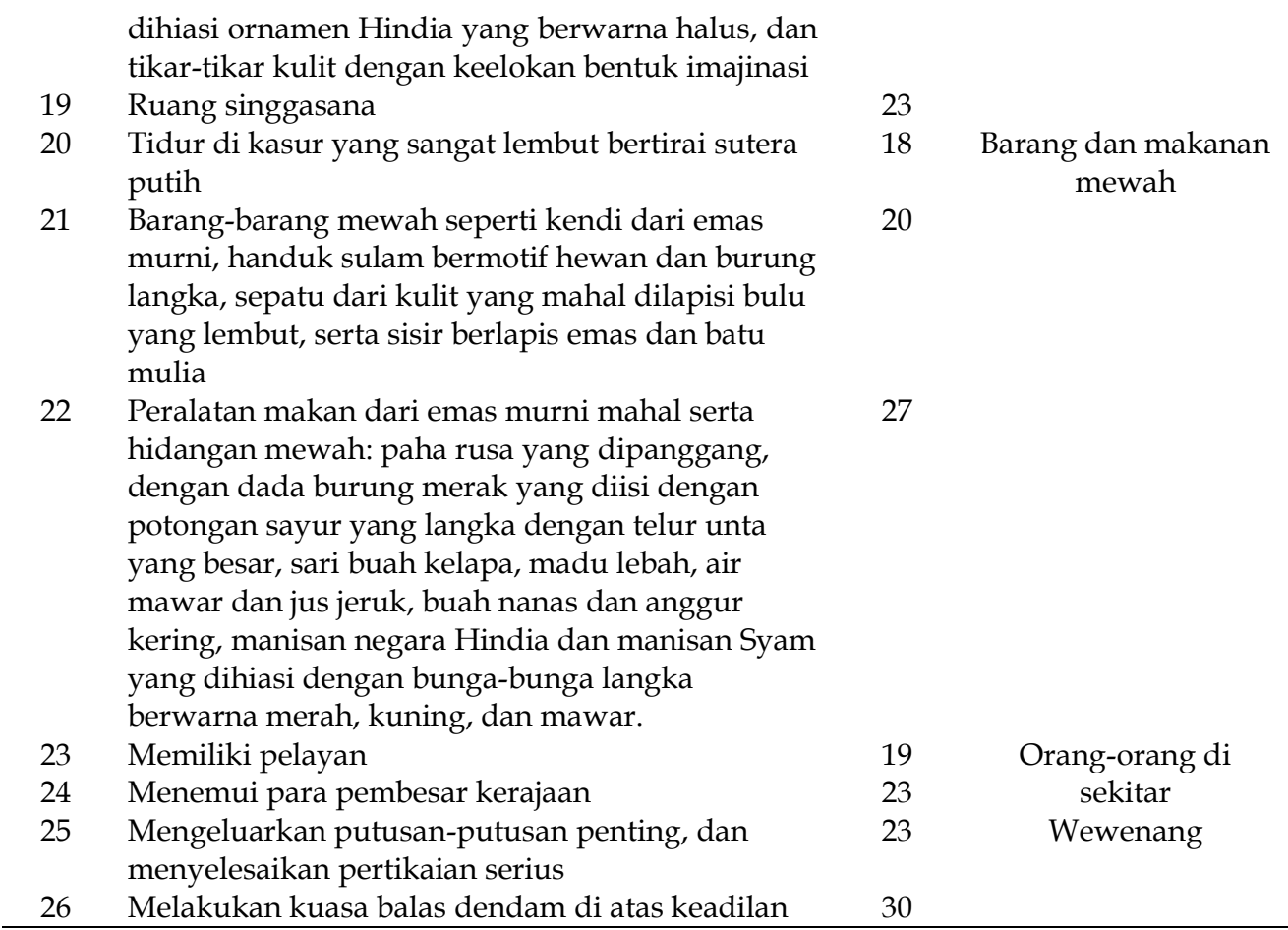

Setelah melalui pembacaan pada teks cerita ditemukan 26 data teks yang diklasifikasikan ke dalam 6 kelompok jenis penanda kekuasaan berdasarkan sistem penandaan Barthes dengan pengembangan ragamnya disesuaikan data temuan, yaitu tanda busana, sikap dan tuturan, tempat tinggal, barang dan makanan mewah, orang-orang di sekitar, serta wewenang raja. Penanda-penanda tersebut mengandung konsep kekuasaan serta makna konotatif yang menunjukkan identitas tokoh raja. Menjadi lazim di dalam budaya masyarakat Bagdad bahwa seorang raja berhak atas semua itu. Nyatanya konsep tersebut (petanda) telah ada sejak lama. Dengan demikian, pengungkapan signifikasi makna dalam cerita ini sangat berpegang pada rujukan kultural sekaligus historis kerajaan di Bagdad, yaitu kerajaan dengan budayanya yang diposisikan sebagai sentral yang terpenting dalam struktur kemasyarakatan Bagdad.

\section{a. Tanda busana}

Terdapat 2 data di dalam teks yang memuat penanda seorang raja, yaitu berupa pakaian mewah yang dijahit emas dan perak serta sorban besar khusus raja. Pengkhususan tersebut sudah menjadi ciri bahwa raja (penguasa) adalah individu berbeda dan istimewa. Barthes (2017: 40) menyebutkan bahwa potongan, bagianbagian pakaian, dan detailnya merupakan variasi yang dapat membawa perubahan makna. Demikian pula pakaian/busana yang dikenakan raja. Pakaian menjadi salah satu wujud prestise seorang raja. Ia juga berfungsi menandakan bahwa individu tersebut adalah seorang raja. Orang yang mengenakannya akan memosisikan dirinya dengan status sebagai raja (penguasa) di tengah masyarakat. Dalam hal ini pakaian dikonstruksi sebagai realitas sebagaimana setiap peristiwa senantiasa dihubungkan 
dengan konvensi-konvensi di masyarakat berdasarkan kepercayaan dominan yang telah melalui proses negosiasi para anggota masyarakat.

Pada masyarakat Arab, penggunaan pakaian dengan jahitan emas dan perak tidak lazim digunakan oleh orang-orang biasa. Pakaian yang mewah berbahan logam mulia mencitrakan posisi pengguna/pemiliknya yang agung, bahwa ia orang istimewa, terpandang, dan memiliki posisi penting dalam kehidupan sosialnya. Derajat yang tinggi sebagaimana emas dan perak yang merupakan logam dengan kualitas yang tinggi di antara jenis logam lainnya. Selain itu, penandaan berharganya emas dan perak pun dibuktikan pada penggunaan dinar dan dirham sebagai alat transaksi tunai/mata uang yang sah di negara-negara Arab. Pakaian mewah yang dijahit emas dan perak tersebut di dalam fashion Arab disebut بِّنت /bisht/. AlMukhtar (2012) menyatakan bahwa bisht telah menjadi pilihan pakaian formal bagi politisi, ulama, dan individu berpangkat tinggi di negara-negara Teluk Arab, Irak, dan negara-negara di utara Arab Saudi. Dengan demikian, penggunaan bisht ini tidak sekadar pakaian dengan fungsi utamanya saja, melainkan sebagai pembeda status sosial. Penggunaan benang emas dan perak pada bisht, sebagaimana dalam cerita Sulthān li Yaumin Wāhid, merupakan elemen bisht termahal yang pernah ada, yang dikenal sebagai The Royal Bisht yang khusus dirancang bagi raja/pangeran, politisi, dan orang-orang kaya tertentu. Dengan demikian, variasi busana seperti itu memunculkan signifikasi tertentu yang mengkhususkan penggunanya adalah orangorang tertentu, seperti juga penutup kepala yang khusus hanya dikenakan oleh raja/penguasa setempat.

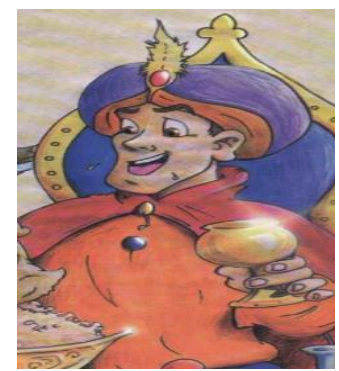

Gambar 1. Ilustrasi busana raja (AsySyaruni, 2008: 28)
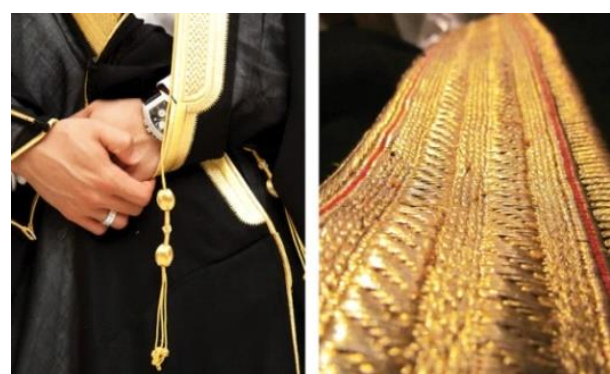

Gambar 2. Busana raja (Al-Mukhtar, 2012)

Pada masa dinasti Abasiyah kepemimpinan Harun Ar-Rasyid pun, sorban hanya digunakan oleh orang-orang penting kerajaan, di antaranya adalah para teolog (Hitti, 2013: 417). Selain sorban, raja pada masa tersebut juga mengenakan /qalansuwah/, topi hitam yang tinggi dan mengerucut yang terbuat dari bahan sintetis atau bulu binatang (Hitti, 2013: 416). Walaupun bisht dan qalansuwah berlaku untuk digunakan oleh tokoh-tokoh penting di negara-negara kerajaan di Arab, namun saat ini hal tersebut tidak ditemukan pada negara Irak seiring dengan perubahan bentuk negara dan pergantian jenis pemerintahannya dari kerajaan (monarki) menjadi republik pada tahun 1958 sehingga hari ini tidak lagi terlihat pemimpin-pemimpin Irak yang mengenakan busana tradisional tersebut dan cenderung berpenampilan lebih modern layaknya para presiden pada umumya dengan jas dan dasi formal. Namun, tampilan busana bisht masih dapat dilihat pada pemimpin Arab Saudi, raja 


\section{Raihan dkk.}

Salman, dalam berbagai aktivitas kenegaraan, salah satunya saat momentum kunjungannya ke Indonesia pada tahun 2017 berikut ini:

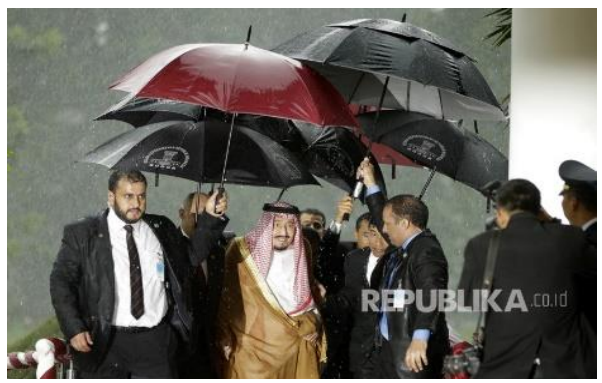

Gambar 3. Raja Arab Saudi dengan busana bishtnya (AP/Ahmad Ibrahim, 2017)

Tentunya dari pakaiannya tersebut jelas menunjukkan bahwa ia berbeda dari yang lainnya, bahwa ia orang penting, dan bahwa ia seorang raja.

\section{b. Sikap dan tuturan}

Sikap dan tuturan yang menjadi penanda kekuasaan Abu Hasan berupa sikap dan tuturannya kepada orang lain maupun sebaliknya. Penandanya dari orang-orang di sekitar raja berupa sikap dan ungkapan penghormatan, pelayanan, serta ketaatan. Adapun penanda dari diri raja sendiri berupa sikap dan ungkapan kebesaran,

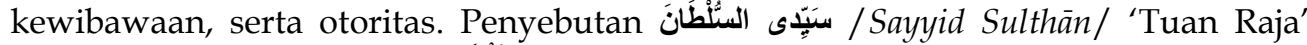
(Asy-Syaruni, 2008: 18) dan مَوْلَاى الستُلْطَانَ / Mawlā Sulthān/ 'Yang Mulia' (Asy-Syaruni, 2008: 20) yang digunakan orang-orang istana untuk menyapa raja jika dimaknai secara denotatif hanya sebuah sapaan normal. Namun, jika penanda tersebut dimaknai secara konotatif, maknanya sampai kepada adanya praktik pembedaan kelas sosial antara raja dengan orang-orang di sekitarnya. Raja menjadi orang yang diistimewakan karena berkedudukan mulia dan tinggi yang harus dilayani segala keperluannya, bahkan prestise dan kedudukan tersebut ditegaskan oleh raja sendiri dalam ucapannya (data nomor 10 dan 14). Abu Hasan bersepakat bahwa dirinya adalah raja yang semua perintahnya harus dijalankan oleh bawahan-bawahannya terlepas dari disetujui atau tidak oleh mereka yang diperintah.

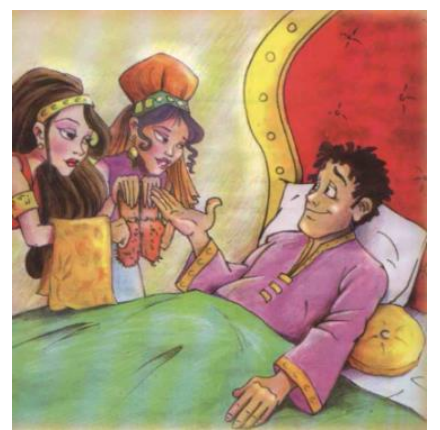

Gambar 4. Pelayanan raja (AsySyaruni, 2008: 25)

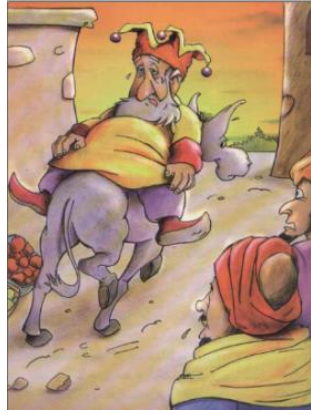

Gambar 5. Hukuman yang otoriter

(Asy-Syaruni, 2008: 25) 
Konotasi raja sebagai pemegang kekuasaan penuh atas segala aspek kehidupan rakyatnya menjadi kebebasan baginya untuk berlaku otoriter, seperti yang dilakukannya pada data nomor 9, 13, dan 15. Untuk data nomor 15 terkait perintah raja memberikan hadiah kepada seorang perempuan lansia (ibu dari Abu Hasan) memiliki kesamaan kisah dengan kebijakan khalifah dinasti Abasiyah kala itu, Harun Ar-Rasyid, yang memberikan santunan 160 juta dirham kepada seorang lansia (ibu dari Harun Ar-Rasyid sendiri) (Hitti, 2013: 378). Berkenaan dengan jumlah dinar yang disumbangkan kepada ibu dari raja, secara logis 5000 dinar emas (Abu Hasan) dan 160 juta dinar emas (Harun Ar-Rasyid) bukan jumlah yang sedikit kecuali jika kerajaan saat itu benar-benar memiliki kekayaan yang sangat berlimpah. Pada kenyataannya, hal itu memang ada pada kemewahan dan kekayaan kehidupan raja Harun Ar-Rasyid (Hitti, 2013: 377).

Selanjutnya untuk data nomor 17 berupa pelayanan anggota istana kepada Abu Hasan sebagai raja sehari di sana menjadi sebuah sikap yang dianggap lazim dilakukan pelayan istana. Kebiasaan pesta dengan mendatangkan para pemusik, penyanyi, dan penari menjadi bagian dari kehidupan keluarga istana sebagaimana juga pernah dilakukan terhadap para khalifah terdahulu, seperti masa dinasti Umayyah, yang sering menikmati hiburan dan jamuan sosial di malam hari setelah sibuk bekerja pada siang hari (Hitti, 2013: 283). Kecenderungan menaturalkan perlakuan dan tuturan khusus bagi raja ini sejalan dengan teori Barthes (2007: 310) yang menyebutkan bahwa konsep berkaitan dengan suatu fungsi serta didefinisikan sebagai kecenderungan. Ia mengemukakan petanda dalam sistem semiologi Freud yang menyatakan bahwa makna tatanan kedua dari perilaku adalah makna sebenarnya atau merupakan maksud perilaku.

\section{c. Tempat Tinggal}

Tempat tinggal menjadi salah satu hal yang disoroti dalam kehidupan seorang raja terkait dengan kemewahannya. Simbol kemewahan yang sangat nampak karena istana khusus disiapkan sebagai tempat tinggal seorang raja yang diagungkan. Diceritakan bahwa istana yang ditempati Abu Hasan pun memiliki pesona dan kenyamanan yang mengagumkan mata rakyat biasa seperti Abu Hasan. Istana kerajaan memiliki kekhasan berupa keberadaan مَقْعَ السُّنُطَان /maq'ad sulthān/ 'ruang singgasana' (data nomor 19) sebagai ruang kebesaran dan kehormatan bagi raja dengan segala interiornya yang mewah dan berharga. Kemewahan tempat tinggal itu menjadi penanda bahwa hanya orang yang memiliki kuasa di bidang kekayaan yang bisa membeli tempat tinggal dengan ruangan-ruangan yang megah dengan biaya yang tidak sedikit tersebut.

Deskripsi ruang kamar kerajaan pun (data nomor 18) sudah cukup menggambarkan bahwa lukisan-lukisan serta interior lainnya hanya dimiliki istana sebagai citra kemewahan terbesar dalam sebuah pemerintahan kerajaan. Dalam sejarah kota Bagdad pun, dikisahkan bahwa istana kerajaan dinasti Abasiyah sangat luas dan disebut-sebut menempati setengah "Kota Lingkaran" itu. Ruang pertemuan dilengkapi dengan karpet, gorden, dan bantal terbaik dari Timur (Hitti, 2013: 375), bahkan istana di Bagdad tersebut beserta segala interiornya menjadi role model istanaistana masa itu dan sesudahnya, khususnya bagi dunia Barat. 


\section{Raihan dkk.}

\section{d. Barang dan makanan}

Data nomor 20 sampai 22 menyebutkan 6 barang mewah istana serta 7 jenis makanan mewah dan langka yang hanya mampu dibeli oleh orang dengan kemampuan ekonomi yang tinggi, tentunya raja Abu Hasan. Sistem perabot rumah tangga sebagaimana yang dimasukkan dalam sistem penandaan Barthes, dalam hal ini barang mewah istana, merepresentasikan kemewahan. Barang-barang tersebut lazimnya tidak dapat dibeli dan dimiliki oleh orang-orang yang "tidak berada". Hitti (2013: 418) pun menyebutkan bahwa peralatan makan dari emas menjadi simbol yang merepresentasikan pemiliknya merupakan orang berada sebagaimana yang pernah menjadi bagian dari kemewahan istana masa dinasti Abasiyah. Disebutkan bahwa pada masa kejayaan Bagdad, salah seorang anggota keluarga kerajaan pun, namanya Zubaidah, menggunakan gelas yang terbuat dari perak atau emas berhias batu berharga. Ia juga menjadi orang pertama yang menghias sepatunya dengan batu berharga (Hitti, 2013: 375). Dengan demikian, barang-barang seperti sutera, peralatan berlapis emas, kain sulam, kulit mahal, serta batu mulia menjadi penanda-penanda kekayaan seorang raja karena benda-benda tersebut "asing" bagi masyarakat biasa. Hal ini sebagaimana yang dikemukakan Barthes (2017: 43) bahwa variasi/ragam "gaya" mengacu pada makna yang berbeda maupun asosiasi dari unit-unit berbeda dalam lingkup tertentu, misalnya perabotan di dalam ruang tertentu seperti ruang makan dan ruang singgasana dalam cerita Sulthān li Yaumin Wähid. Keberadaan penanda-penanda tersebut secara tidak langsung menjadi pembeda yang lazim bagi dua kelas masyarakat karena secara konotatif barang-barang tersebut sudah mengandung makna kekuasaan dan kekayaan seseorang yang dalam cerita Sulthān li Yaumin Wähid adalah raja.

Selain barang, penanda-penanda tersebut juga berupa makanan mewah yang dihidangkan hanya di meja makan istana; paha rusa yang dipanggang, dada burung merak yang diisi dengan potongan sayur yang langka dengan telur unta yang besar, sari buah kelapa, madu lebah, air mawar dan jus jeruk, buah nanas dan anggur kering, manisan negara Hindia dan manisan Syam yang dihiasi dengan bunga-bunga langka berwarna merah, kuning, dan mawar (data nomor 22). Jenis makanan seperti itu merupakan variasi yang khas hanya bagi keluarga kerajaan/istana. Pada umumnya, makanan masyarakat Irak berupa daging ayam, sapi, dan domba serta ikan Masgouf. Adapun makanan utama mereka berupa gandum, nasi, dan kurma. Dengan demikian makanan-makanan di istana Abu Hasan sudah tentu merupakan makanan mewah yang tidak dikonsumsi oleh masyarakat Bagdad (Irak) pada umumnya. Demikian pula dengan minuman sirup di masa dinasti Abasiyah yang menjadi pengganti minuman beralkohol yang dibuat dari air yang dimaniskan dengan gula dan diberi aroma dari sari pisang, mawar, atau arbei (Hitti, 2013: 418).

\section{e. Orang-orang Dekat}

Pada cerita Sulthān li Yaumin Wāhid tersebut, orang-orang dekat juga menjadi penanda penting kekuasaan raja. Para pelayan yang setia melayani raja setiap waktu serta para pembesar kerajaan termasuk menteri agung dan gubernur yang harus patuh terhadap putusan-putusan raja menunjukkan posisi raja Abu Hasan sebagai orang penting di tengah mereka. Menjadi hal lazim ketika melihat eksistensi seorang raja melalui orang-orang yang mengelilingi kehidupannya sehari-hari, bahkan hal tersebut telah berlangsung sejak lama. Pada zaman dahulu pun khalifah dibantu oleh 
seorang pejabat rumah tangga istana yang bertugas memperkenalkan para utusan dan pejabat yang akan mengunjungi khalifah sehingga pengaruhnya di istana menjadi cukup besar serta ada juga wazir sebagai tangan kanan khalifah (Hitti, 2013: 396-397).

\section{f. Wewenang}

Data nomor 25 dan 26 merupakan beberapa pekerjaan yang melekat dengan tugas dan wewenang seorang raja/penguasa. Mengeluarkan putusan penting, menyelesaikan pertikaian serius, termasuk wewenang yang menggambarkan karakter pemerintahannya yang otoriter, seperti melakukan kuasa balas dendam terhadap orang tertentu dengan memanfaatkan kedudukannya di dalam sebuah pemerintahan. Di dalam cerita Sulthān li Yaumin Wāhid, Abu Hasan menggunakan kesempatan seharinya menjadi raja (pada kesempatan pertama) untuk membalaskan dendamnya kepada orang-orang yang dianggap telah menyakitinya (data nomor 13). Putusan yang subjektif dan tanpa alasan tersebut pada kenyataannya tetap diterima oleh rakyatnya tanpa ada resistensi karena putusan tersebut diperintahkan oleh raja mereka sebagai satu-satunya penguasa yang dipatuhi di wilayah tersebut. Mereka berada di bawah kuasa kepatuhan kepada raja mereka walaupun ada yang diperlakukan secara semena-mena. Hal itu terjadi karena raja menjadi sentral dalam kehidupan pemerintahan dan masyarakat. Raja bebas untuk memerintah dan mengatur hukum. Ia memenangkan segala kapital yang memosisikannya pada hierarki kekuasaan tertinggi. Segala kapital ia kuasai sehingga memperkuat posisi di pemerintahannya serta mempengaruhi karakter tokoh dalam memutuskan urusan kerajaan. Posisinya memberinya kesempatan untuk bebas berbuat, baik menjadi raja yang arif atau raja yang semena-mena. Rakyat menerima begitu saja tanpa melakukan protes serta menganggap raja berhak memperlakukan mereka seperti apapun, termasuk hingga kekerasan fisik.

\section{PENUTUP}

Berdasarkan temuan di dalam cerita yang dikorelasikan dengan teori penandaan Barthes, dapat disimpulkan bahwa di dalam cerita anak Sulthān li Yaumin Wāhid terdapat bentuk praktik kekuasaan raja yang dinaturalisasi oleh masyarakat Bagdad sehingga nampak normal sebagai bagian dari kultur kehidupan masyarakat Bagdad. Naturalisasi berkelanjutan tersebut menciptakan kekebalan terhadap praktik dominasi yang dilakukan tokoh raja Abu Hasan dengan tidak adanya resistensi dari rakyatnya sebagai tokoh yang didominasi. Kondisi tersebut diketahui melalui penanda-penanda kekuasaan pada tokoh raja yang menjadi identitas khas baginya sebagai seorang penguasa. Tradisi ini tidak dapat dipungkiri merupakan bagian dari realitas sosial. Praktik kekuasaan yang diterapkan pada hierarki kerajaan dalam cerita anak Sulthān li Yaumin Wāhid pun masih diterapkan oleh penguasa dalam konteks yang beragam, tidak hanya raja dan kerajaannya. Apapun yang biasa dipakai, dikerjakan, dan dikonsumsi mewakili kelas sosial serta posisinya di masyarakat. Abu Hasan yang hidup dalam lingkungan istana membentuk dirinya pada peran-peran utama anggota istana, seperti kebiasaan makan dan aktivitasaktivitas raja.

Pada cerita yang berkonteks masyarakat Bagdad tersebut, terdapat 6 jenis penanda kekuasaan raja berupa busana, sikap dan tuturan, tempat tinggal, barang 


\section{Raihan dkk.}

dan makanan, orang-orang dekat, serta wewenang raja. Pakaian bisht maupun sorban sejenis qalansuwah menandakan level orang berkelas karena merupakan pakaian yang berbeda dengan orang lain. Sapaan 'Tuan Raja' dan 'Yang Mulia' menandakan raja sebagai orang yang paling istimewa dan mulia yang harus dilayani, dipatuhi, serta diberikan wewenang paling besar dalam segala urusan oleh orang-orang di sekitarnya. Adapun istana dengan segala barang mewah dan makanan mewah di dalamnya mengkonotasikan tingginya taraf hidup raja. Semua jenis penanda tersebut menggambarkan keadaan (sifat dan karakter) seorang penguasa di lingkungannya. Penanda-penanda tersebut juga bersifat kultural karena dalam waktu yang lama "ditetapkan" sebagai unsur-unsur yang melekat pada seorang raja di Bagdad serta mengacu pada lingkup kekuasaannya atas rakyatnya.

\section{DAFTAR PUSTAKA}

Al-Mukhtar, R. (2012). Traditional \& Modern: The Saudi Man's Bisht, Arab News. Retrieved from https:/ / www.arabnews.com/fashion/traditional-modernsaudi-mans-bisht

Anggoro, A. R. P. (2016). Konsep-konsep Dasar Semiotika Struktural Pada Momen Ilmiah Roland Barthes. Institut Seni Indonesia, Surakarta. Retrieved from repository.isi-ska.ac.id

AP/Ahmad Ibrahim, P. (Producer). (2017, 29 November 2020). Kunjungan Raja Salman Bukan Hanya Kenegaraan, Tapi Kekeluargaan. Retrieved from https://republika.co.id/berita/om4tyx366/kunjungan-raja-salman-bukanhanya-kenegaraan-tapi-kekeluargaan

Asy-Syaruni, Y. q. (2008). Sulthan li Yaumin Wahid. Kairo: Darul Ma'arif.

Barthes, R. (2007). Membedah Mitos-mitos Budaya Massa: Semiotika atau Sosiologi Tanda, Simbol, dan Representasi (I. Mahyuddin, Trans.). Yogyakarta dan Bandung: Jalasutra.

Barthes, R. (2017). Elemen-elemen Semiologi (M. Ardiansyah, Trans.). Yogyakarta: Basabasi.

Hitti, P. K. (2013). History of The Arabs (C. L. Yasin \& D. S. Riyadi, Trans. 10 ed.). Jakarta: PT Serambi Ilmu Semesta.

Lustyantie, N. (2012). Pendekatan Semiotik Model Roland Barthes dalam Karya Sastra Prancis. Paper presented at the Seminar Nasional FIB UI, Universitas Indonesia. www.academia.edu

Piliang, Y. A. (2004). Semiotika Teks: Sebuah Pendekatan Analisis Teks. Mediator, $5(2), 189-198$.

Wibowo, I. S. W. (2013). Semiotika Komunikasi: Aplikasi Praktis Bagi Penelitian dan Skripsi Komunikasi (2 ed.). Jakarta: Mitra Wacana Media.

Zaimar, O. K. S. (2008). Semiotik dan Penerapannya Dalam Karya Sastra. Jakarta: Pusat Bahasa Departemen Pendidikan Nasional. 